\title{
Wykorzystanie zmodyfikowanego profilu umiejętności słuchowych w obserwacji efektów rehabilitacji słuchu dorosłych pacjentów z częściową głuchotą korzystających z systemu implantu ślimakowego - doniesienie wstępne
}

\section{Application of modified auditory skill profile in observation of hearing rehabilitation effects of adult partially deaf patients who use cochlear implant systems}

\author{
Agnieszka Pankowska ${ }^{1,2}$, Joanna Solnica ${ }^{1,2}$, Henryk Skarżyński ${ }^{1,2}$ \\ ${ }^{1}$ Instytut Fizjologii i Patologii Słuchu, ul. Zgrupowania AK „Kampinos” 1, 01-943 Warszawa \\ ${ }^{2}$ Światowe Centrum Słuchu, ul. Mokra 17, Kajetany, 05-830 Nadarzyn
}

Adres autora: Agnieskza Pankowska, Światowe Centrum Słuchu, ul. Mokra 17, Kajetany, 05-830 Nadarzyn; tel 22 3560335, e-mail: a.pankowska@ifps.org.pl

\section{Streszczenie}

\begin{abstract}
Wstęp: W grupie dorosłych pacjentów z częściową głuchotą znaczącą większość stanowią osoby, których problemy z odbiorem i rozumieniem mowy rozpoznane zostały po 7. roku życia. Mimo umiejętności porozumiewania się słownego, odczuwają duże ograniczenia w śledzeniu mowy, w możliwości komunikowania się, zwłaszcza w gronie kilku rozmówców i/lub na tle dźwięków zakłócających. Po operacji wszczepienia implantu ślimakowego i aktywacji systemu, uzyskują możliwość odbioru dźwięków z całego pasma częstotliwości. Dzięki właściwie organizowanemu treningowi słuchowemu, uczą się integrować wrażenia akustyczne odbierane za pomocą słuchu naturalnego z wrażeniami dostarczanymi za pomocą implantu ślimakowego. Nabywane umiejętności powinny być jednak systematycznie obserwowane i udostępniane pacjentowi w możliwie czytelnej formie.
\end{abstract}

Materiał i metoda: Badaniami objęto 24 dorosłych pacjentów (19 kobiet i 5 mężczyzn) z częściową głuchotą - użytkowników systemu implantu ślimakowego; 6 pacjentów korzysta z CI krócej niż 6 miesięcy, 12 osób ponad 6 miesięcy, u 3 pacjentów minął rok od pierwszego podłączenia procesora mowy, a 3 osoby korzystają z systemu ponad 24 miesiące.

W celu obserwacji i oceny efektów rehabilitacji wykorzystano zmodyfikowany zestaw zadań testowych, dotyczących umiejętności słuchowych. Otrzymane wyniki wykorzystano do tworzenia indywidualnego „profilu umiejętności słuchowych pacjenta”, czyli graficznej ilustracji obserwowanych rezultatów.

Wyniki: W badaniach prowadzonych w oparciu o 18 zadań testowych, w ośmiu z nich już po upływie 1 miesiąca korzystania z procesora mowy 24 pacjentów uzyskało wynik 100\% rozpoznania. Zmiany obserwowaliśmy natomiast w pozostałych 10 zadaniach testowych. W omawianej grupie sporządzono 3 kompletne profile umiejętności słuchowych.

Wnioski: Uzyskiwane przez pacjentów wyniki potwierdziły, że zaproponowany pilotażowo materiał do obserwacji efektów rehabilitacji dla omawianej grupy pacjentów, ma wartość diagnostyczną. Formuła tworzonego na ich podstawie profilu umiejętności słuchowych pacjenta dostarcza czytelnych informacji zarówno dla pacjenta, jak i dla terapeuty. Pozwala wyznaczać właściwe zadania na kolejne etapy rehabilitacji.

Słowa kluczowe: implanty ślimakowe • pacjenci z częściową głuchotą • Profil Umiejętności Słuchowych

Abstract

Background: Within a group of adult partially deafened patients there is a group whose impairment and problems with speech perception and understanding were diagnosed after the 7 year of age. Despite the fact that they use speaking language they experience significant difficulties in speech perception and communication, especially in noisy environments with other sounds interfering. After the cochlear implantation and system activation they have a possibility to perceive sounds from the whole 
frequency band. Properly organized hearing training helps them to combine acoustic sensations perceived with the natural hearing and sensations provided electrically using a cochlear implant. Acquired skills should be supervised and presented to the patient in the most friendly way.

Material and method: Material includes 24 adult patients (19 females i 5 males) with partial deafness. All of them use cochlear implants. 6 patients have been using the CI for no more than 6 months. 12 subjects have been using the CI for more than 6 months, 3 of them have been using the CI for more than a year and 3 people have been using the CI for more than 24 months.

To monitor and provide appropriate assessment of the effects a battery of tests was modified, prepared and used. The obtained results were used to organize an individual „profile of patient's hearing skills” - a graphic illustration of obtained results.

Results: Research was based on 18 tasks. In the 8 of them 24 patients obtained the result of $100 \%$ identification just one month after first speech processor fitting. Significant changes, however were observed in the remaining 10 tasks. 3 complete profiles of the patients hearing skills were created.

Conclusions: Results obtained by the patients confirm that the set of supervision materials designed to control the effects of rehabilitation and proposed as pilot study is valuable and can be used in diagnostics. Formula developed on the basis of auditory skill profile of the patient provides clear information on patient's progress (both to a patient and a therapist). It helps to determine exercises for the next stages of rehabilitation.

Key words: cochlear implants • partial deafness patients • auditory skill profile

\section{Wstęp}

Włączenie w 2002 roku do programu leczenia z wykorzystaniem implantu ślimakowego osób z częściową głuchotą [Skarżyński, Lorens, Piotrowska 2003] stworzyło konieczność modyfikacji programu terapii oraz narzędzi stosowanych do oceny efektów rehabilitacji właściwych dla potrzeb tej nowej grupy pacjentów. Najczęściej obserwowane trudności charakterystyczne dla osób dorosłych, u których wynik badania audiologicznego potwierdził diagnozę częściowej głuchoty, to przede wszystkim: ograniczone możliwości odbioru, różnicowania i rozpoznawania dźwięków z otoczenia (zarówno w ciszy, jak i na tle dźwięków zakłócających), odbiór mowy ze wsparciem kanału wzrokowego (obserwacja twarzy rozmówcy, odczytywanie mowy z ust), ograniczenia w śledzeniu i rozpoznawaniu treści wypowiedzi słownych w różnych warunkach akustycznych, znaczące ograniczenia w różnicowaniu i rozpoznawaniu słów o podobnym brzmieniu oraz zaburzenia prozodii i artykulacji przy zachowanej komunikacji werbalnej na poziomie zdań wielowyrazowych, poprawnych gramatycznie. Wiemy już dziś, że dzięki zastosowaniu implantu ślimakowego udało się z powodzeniem połączyć naturalne słyszenie ze słyszeniem „elektrycznym”. Pacjenci uzyskali możliwość odbioru dźwięków z całego pasma częstotliwości. Jednak dopiero właściwie organizowany trening słuchowy służyć ma integracji wrażeń akustycznych odbieranych za pomocą słuchu naturalnego $\mathrm{z}$ wrażeniami dostarczanymi za pomocą implantu ślimakowego. W organizacji programu pooperacyjnej rehabilitacji słuchu w omawianej grupie pacjentów wykorzystywane są metody stosowane w pracy z użytkownikami systemu implantu ślimakowego z głębokim ubytkiem słuchu lub całkowitą głuchotą, modyfikacji poddawany jest natomiast materiał dźwiękowy i leksykalny.

Celem pracy jest przedstawienie wstępnych doniesień na temat obserwacji efektów terapii słuchu dokonywanych $\mathrm{z}$ wykorzystaniem formuły zmodyfikowanego profilu umiejętności słuchowych [Skarżyński, Szuchnik, Mueller-Malesińska 2004] stworzonego przez specjalistów z Kliniki Rehabilitacji Instytutu Fizjologii i Patologii Słuchu.

\section{Material i metoda}

W ramach prób stworzenia indywidualnego profilu umiejętności słuchowych obserwowano efekty treningu słuchowego w grupie 24 dorosłych pacjentów (19 kobiet i 5 mężczyzn) z częściową głuchotą - użytkowników systemu implantu ślimakowego. W omawianej grupie u 18 osób zaburzenia słuchu określane aktualnie mianem częściowej głuchoty wykryte zostały w wieku po 7. r. ż. (pacjenci postlingwalni)., a u 6 osób w okresie opanowywania mowy, czyli między 3-7 r. ż (pacjenci periligwalni). Wszystkie osoby komunikują się werbalnie na poziomie zdań wielowyrazowych, zachowując poprawność gramatyczną tworzonych wypowiedzi słownych. Na etapie diagnostyki przedoperacyjnej za największą zgłaszaną trudność uznały one „brak rozumienia mowy”. Według podziału zaproponowanego przez profesora Henryka Skarżyńskiego [Skarżyński, Lorens, Piotrowska, Skarżyński 2010.], 23 pacjentów należy do grupy określanej mianem EAS, tzn. pacjentów korzystających jednocześnie ze stymulacji elektryczno-akustycznej, a jedna pacjentka należy do grupy określanej jako ES, tzn. korzysta ze stymulacji elektrycznej przy zachowanym prawidłowym słuchu w zakresie niskich częstotliwości. W programie rehabilitacji słuchu (systematyczne wizyty co najmniej $1 \mathrm{raz}$ w miesiącu) prowadzonym w Klinice Rehabilitacji IFPS od dnia pierwszego podłączenia procesora mowy uczestniczyło 11 z 24 pacjentów. U pozostałych osób wizyty rehabilitacyjne nie zawsze przebiegały regularnie. 6 pacjentów korzysta z CI krócej niż 6 miesięcy, 12 osób ponad 6 miesięcy, u 3 pacjentów minął rok od pierwszego podłączenia procesora mowy, a 3 osoby korzystają z systemu ponad 24 miesiące.

Zajęcia rehabilitacyjne obejmowały ćwiczenia słuchowe: z wykorzystaniem dźwięków otoczenia (zwłaszcza 
o średniej i wysokiej częstotliwości); z wykorzystaniem spółgłosek w sylabach; z wykorzystaniem par wyrazów o podobnym brzmieniu (wyrazy różnią się spółgłoskami); z wykorzystaniem zdań w zestawie zamkniętym, półotwartym, otwartym; z wykorzystaniem słów jednosylabowych, gdzie, $\mathrm{w}$ prezentowanym pacjentom materiale słownym zawarte w przykładach sylab, wyrazów czy zdań spółgłoski $(\dot{s}, \dot{z}, \dot{c}, \breve{Z}, s, z, c, \mathcal{Z}, \check{s}, \check{z}, \check{c}, \breve{Z}, p, t, n, m, k, f, \chi)$ należą do grupy tych głosek języka polskiego, których odbiór, różnicowanie czy rozpoznawanie przed zastosowaniem implantu ślimakowego był znacznie ograniczony lub niemożliwy.

Zgodnie z przyjętym założeniem monitorowanie efektów prowadzonej stymulacji słuchu $\mathrm{z}$ wykorzystaniem formuły profilu umiejętności słuchowych zaplanowano tak, iż pacjenci poddawani będą ocenie odpowiednio po upływie 1., 6., 12. i 24. miesięcy od pierwszego podłączenia procesora mowy. $W$ tym celu przebadani zostaną testami $\mathrm{z}$ listy narzędzi, jaka stosowana była w przypadku osób dorosłych z całkowitą głuchotą bądź niedosłyszących w stopniu głębokim [Skarżyński, Szuchnik, Mueller-Malesińska 2004.]. Z pierwotnej wersji zestawu zadań testowych wycofano testy o niższym stopniu trudności - odpowiednio z poziomów I, II i III - czyli zestaw TAPS i test „Onomatopeje” oraz próby związane z integracją odbioru wzrokowego i słuchowego (odczytywania mowy z ust), a z Poziomu I z zakresu zadań obejmujących dyskryminację cech segmentalnych wybrany został tylko 1 test TSRG (Test Słuchowego Różnicowania Głosek). Przygotowana wstępnie lista testów obejmowała więc 13 prób.
Następnie w ramach narzędzi Poziomu I, II i III wprowadzono dodatkowo możliwość oceny poprzez wykorzystanie zmodyfikowanych prób z wykorzystaniem materiałów autorskich stworzonych przez terapeutów z Kliniki Rehabilitacji IFPS. Odpowiednio:

Poziom I - podstawowy rozbudowano o:

- zadanie $4 \mathrm{a}^{*}$ - próba na bazie testu TSRG ze zmodyfikowanym materiałem słownym;

- zadanie $6^{\star}$ - próba stworzona na bazie testu SERT (Sound Effects Recognition Test) [Finitzo-Hieber, Gerling, Matkin, Cherow-Skalka 1980.] ze zmodyfikowanym zestawem dźwięków(obejmujących zwłaszcza sygnały z zakresu wysokich częstotliwości).

Poziom II - zwykłej rozmowy rozbudowano o:

- zadanie $8 \mathrm{f}^{*}$ - próba na bazie testu MED-EL ze zmodyfikowanym zestawem sylab.

Poziom III - rozumienia mowy rozbudowano o:

- zadanie $11 c^{\star}$ - próba na bazie testu MED-EL ze zmodyfikowanym zestawem zdań;

- zadanie $12^{*}$ - rozumienie słów jednosylabowych - badania w szumie, przeprowadzane w kabinie.

We wszystkich przypadkach, gdzie zastosowano zmodyfikowane wersje testów wykorzystane zostały zasady przeprowadzania badania i układ zadań przypisane do wersji oryginalnych. Po tych zmianach lista narzędzi, którymi dysponowali terapeuci prowadzący obejmowała łącznie 18 zadań. Przeprowadzone zmiany i stosowane oznakowanie zadań ilustruje Tabela 1.

Tabela 1. Profil Umiejętności Słuchowych - wykaz 18 zadań testowych badających określone sprawności

\begin{tabular}{|c|c|}
\hline $\begin{array}{c}\text { Dla pacjentów z całkowitą głuchotą lub głębokim ubytkiem } \\
\text { słuchu, korzystających z Cl }\end{array}$ & Dla dorosłych pacjentów z częściową głuchotą, korzystających z Cl \\
\hline \multicolumn{2}{|c|}{ Poziom I - podstawowy } \\
\hline 1. wykrywanie dźwięków mowy (TAPS - kategoria 1) & 1. wycofano w badanej grupie \\
\hline 2. dyskryminacja cech sylab (TAPS - kategoria 2A) & 2. wycofano w badanej grupie \\
\hline 3. dyskryminacja cech suprasegmentalnych („Onomatopeje”) & 3. wycofano w badanej grupie \\
\hline 4. dyskryminacja cech segmentalnych & 4. dyskryminacja cech segmentalnych \\
\hline \multirow[t]{2}{*}{ a. TSRG } & a. TSRG \\
\hline & $a^{*}$. TSRG ze zmodyfikowanym materiałem słownym \\
\hline b. „Chiński Język” & b. wycofano w badanej grupie \\
\hline 5. dyskryminacja samogłosek w wyrazach („Samogłoski”) & 5. dyskryminacja samogłosek w wyrazach („Samogłoski”) \\
\hline \multirow[t]{2}{*}{ 6. identyfikacja dźwięków z otoczenia („12 dźwięków”) } & 6. identyfikacja dźwięków z otoczenia („12 dźwięków”) \\
\hline & $\begin{array}{l}\text { 6*. próba stworzoną na bazie testu SERT ze zmodyfikowanym } \\
\text { zestawem dźwięków }\end{array}$ \\
\hline \multicolumn{2}{|c|}{ Poziom II - zwykłej rozmowy } \\
\hline 7. identyfikacja mowy na podstawie cech suprasegmentalnych & 7. identyfikacja mowy na podstawie cech suprasegmentalnych \\
\hline a. na podstawie długości wyrazu (skrining A) & a. na podstawie długości wyrazu (skrining A) \\
\hline b. na podstawie długości zdania (skrining B) & b. na podstawie długości zdania (skrining B) \\
\hline c. wzór sylab syntetycznych (TAPS - kategoria 2B) & c. wycofano w badanej grupie \\
\hline d. percepcja sylab w wyrazach (TAPS - kategoria 2C) & d. wycofano w badanej grupie \\
\hline e. cechy prozodyczne mowy („Onomatopeje”) & e. wycofano w badanej grupie \\
\hline
\end{tabular}


Tabela 1 c.d. Profil Umiejętności Słuchowych - wykaz 18 zadań testowych badających określone sprawności

\begin{tabular}{|c|c|}
\hline $\begin{array}{c}\text { Dla pacjentów z całkowitą głuchotą lub głębokim ubytkiem } \\
\text { słuchu, korzystających z Cl }\end{array}$ & Dla dorosłych pacjentów z częściową głuchotą, korzystających z Cl \\
\hline 8. identyfikacja mowy na podstawie cech segmentalnych & 8. identyfikacja mowy na podstawie cech segmentalnych \\
\hline a. identyfikacja słów na podstawie 2 formantu (skrining C) & a. identyfikacja słów na podstawie 2 formantu (skrining C) \\
\hline b. identyfikacja słów (TAPS - kategoria 3A) & b. wycofano w badanej grupie \\
\hline c. identyfikacja zdań (TAPS - kategoria 3B) & c. wycofano w badanej grupie \\
\hline d. identyfikacja samogłosek w wyrazach („Samogłoski”) & d. identyfikacja samogłosek w wyrazach („Samogłoski”) \\
\hline e. identyfikacja samogłosek w sylabach (zestaw testów MED-EL) & e. identyfikacja samogłosek w sylabach (zestaw testów MED-EL) \\
\hline \multirow[t]{2}{*}{ f. identyfikacja spółgłosek w sylabach (zestaw testów MED-EL) } & f. identyfikacja spółgłosek w sylabach (zestaw testów MED-EL) \\
\hline & $\begin{array}{l}f^{\star} \text {. próba na bazie testu MED-EL ze zmodyfikowanym zestawem } \\
\text { sylab }\end{array}$ \\
\hline 9. identyfikacja wypowiedzi ze wskazówką tematyczną & 9. identyfikacja wypowiedzi ze wskazówką tematyczną \\
\hline a. identyfikacja liczb od 1 do 100 & a. identyfikacja liczb od 1 do 100 \\
\hline $\begin{array}{l}\text { b. rozpoznawanie zdań dotyczących określonego tematu } \\
\text { (TAPS - kat. 5A i 5B) }\end{array}$ & b. wycofano w badanej grupie \\
\hline $\begin{array}{l}\text { 10. odczytywanie mowy z ust - integracja odbioru } \\
\text { wzrokowego i słuchowego (TAPS - kat. 4) }\end{array}$ & c. wycofano w badanej grupie \\
\hline
\end{tabular}

\begin{tabular}{lc}
\hline & Poziom III - rozumienia mowy \\
\hline 11. słuchowe rozumienie mowy wiązanej & 11. słuchowe rozumienie mowy wiązanej \\
\hline a. rozumienie poleceń (TAPS - kategoria 5C) & a. wycofano w badanej grupie \\
\hline b. rozumienie prostych zdań (skrining D) & b. rozumienie prostych zdań (skrining D) \\
\hline c. rozumienie zdań (zestaw testów MED-EL) & c. rozumienie zdań (zestaw testów MED-EL) \\
\hline $\begin{array}{l}\text { 12. słuchowe rozumienie słów 1-sylabowych (listy } \\
\text { artykulacyjne - Poznań) }\end{array}$ & \begin{tabular}{c} 
c*.próbanabazietestuMED.-ELzezmodyfikowanymzestawemzdań \\
\hline
\end{tabular} \\
$\begin{array}{c}\text { 12. słuchowe rozumienie słów 1-sylabowych (listy artykulacyjne } \\
\text { - Poznań) - badanie w kabinie }\end{array}$ \\
$\begin{array}{c}\text { 12*. słuchowe rozumienie słów jednosylabowych - badania } \\
\text { w szumie, próba prowadzona w kabinie. }\end{array}$
\end{tabular}

Decyzja o modyfikacji listy narzędzi wynikała $\mathrm{z}$ analizy zawartych w ww. testach prób, informacji zebranych na etapie diagnostyki przedoperacyjnej (dotyczących specyficznych ograniczeń w odbiorze i rozpoznawaniu dźwięków z otoczenia i mowy wynikających z faktu częściowej głuchoty), obserwacji możliwości i umiejętności pacjentów oraz przyjętym programie rehabilitacji słuchu. Zadania Poziomu I., II. i częściowo III. (bez 12 i $12^{\star}$ ) były przeprowadzane w naturalnych warunkach akustycznych, w gabinecie terapeuty. Zadania 12 i $12^{*}$ - prowadzone w kabinie. Materiał dźwiękowy (dźwięki z otoczenia) oraz wyrazowy (słowa jednosylabowe) był odtwarzany z płyt CD. Pozostałe próby przeprowadzano „żywym głosem. Podczas badania pacjent korzystał wyłącznie z systemu implantu ślimakowego. Wyniki pacjentów w wykorzystanych do badań zadaniach testowych wprowadzane są do indywidualnej „tabeli wyników”, a następnie, na ich podstawie może być sporządzony „profil umiejętności słuchowych pacjenta”.

\section{Wyniki}

U 6 osób, które korzystają z implantu ślimakowego krócej niż 6 miesięcy, przeprowadzono dotychczas tylko 1 pomiar, jednak w 2 przypadkach nie wykorzystano pełnego zestawu prób. W odniesieniu do 12 pacjentów posiadamy wyniki z 1 . i 6. miesiąca korzystania z CI, obejmujące zmodyfikowane zadania testowe. W obserwowanej grupie pacjentów u 3 osób zebrano wyniki z 1., 6.,i 12. miesiąca, a u 3 osób ze wszystkich czterech ustalonych okresów. Wyniki uzyskane w całej grupie (24 pacjentów) w badaniu po upływie 1. miesiąca korzystania $\mathrm{z}$ implantu ślimakowego wynoszą $100 \%$. dla zadań $5,6,7 \mathrm{a}, 7 \mathrm{~b}, 8 \mathrm{a}, 8 \mathrm{~d}, 9 \mathrm{a} 11 \mathrm{~b}$. W badaniu po upływie 6 miesięcy powtórzono je w grupie 18 pacjentów i również wszystkie osoby osiągnęły wynik 100\%. Zmiany obserwowaliśmy natomiast $\mathrm{w}$ pozostałych testach $\mathrm{z}$ zestawu, zarówno tych wykorzystywanych wcześniej do oceny nabywanych umiejętności słuchowych w gronie pacjentów z całkowitą głuchotą lub głębokim ubytkiem słuchu (zadania: 4a, 8e, 8f, 9a, 11c, i 12), jak i w próbach zmodyfikowanych (zadania: $4 a^{*}, 6^{*}, 8 \mathrm{f}^{\star}, 11 \mathrm{c}^{\star}, 12^{\star}$ ). Zadania te odpowiadały ściśle celom treningu słuchowego prowadzonego w grupie dorosłych pacjentów z częściową głuchotą $\mathrm{i}$, jak wynika $\mathrm{z}$ opinii naszych pacjentów, stanowią dla nich największe wyzwanie. Na podstawie otrzymanych danych przygotowywane są indywidualne profile umiejętności słuchowych.

Poniżej przedstawiono przykłady 3 kompletnych wykresów „profilów umiejętności słuchowych”, będących 
efektem prowadzonych badań wraz z krótką informacją o pacjentach oraz audiogramem wykonanym przed operacją wszczepienia implantu ślimakowego.

Pacjentka E. D.

Pacjentka z postlingwalną utratą słuchu w zakresie średnich i wysokich częstotliwości. Komunikuje się werbalnie, głos miły, dźwięczny, buduje zdania wielowyrazowe, poprawne gramatycznie, wymowa głosek czytelna. Problemy ze słuchem zaczęły się ok. 20 lat przed operacją. Początkowo korzystała $z$ aparatów słuchowych, jednak rok przed operacją przestała, ponieważ w subiektywnej ocenie nie przynosiły pożądanych efektów w zakresie odbioru sygnałów mowy. Odbiór mowy odbywał się w oparciu o kanał wzrokowo-słuchowy. Motywacją do poddania się operacji były: znaczny wysiłek wkładany w codzienne funkcjonowanie, narastające ograniczenia, trudności dotyczące rozumienia mowy, zwłaszcza przy dźwiękach zakłócających, jak również towarzystwie kilku osób. Pacjentka została zoperowana w lipcu 2009 r. i otrzymała implant ślimakowy NUCLEUS FREEDOM SRA do ucha prawego, do którego w sierpniu 2009 r. podłączono procesor mowy, a w następnej kolejności dopasowano część akustyczną dla wzmocnienia niskich częstotliwości. W momencie podłączenia procesora mowy pacjentka miała 65 lat (Rycina 1A,B).
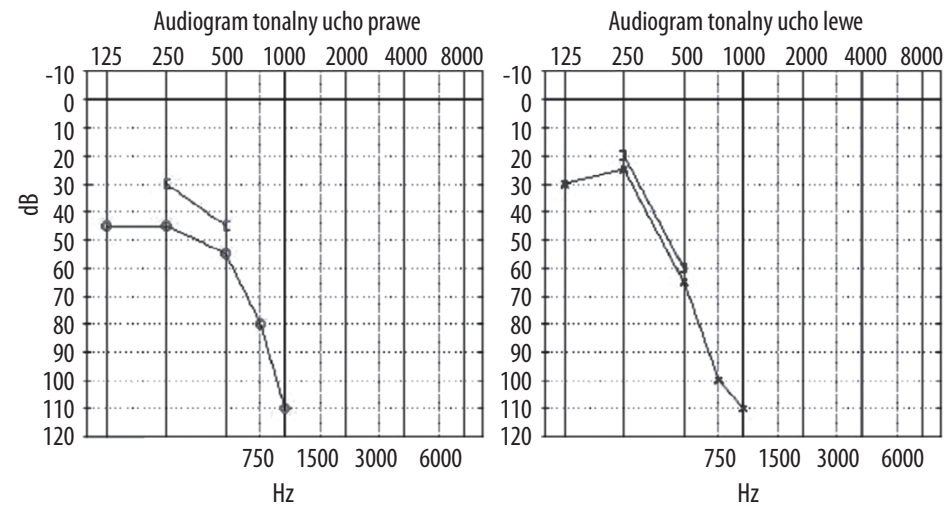

Rycina 1A. Audiogram pacjentka E.D.

\section{PROFIL UMIEJĘTNOŚCI SŁUCHOWYCH PACJENTA}

Pacjent .......D.

Wiek w momencie zaimplantowania $\ldots .65$ lat

Przyczyna gluchoty gluchota postępująca

- postlingwalna
Typ implantu HYBRID (EAS)/bezaparatunadrugie ucho

Data pierwszego podłączenia procesora mowy 17. 08.2009

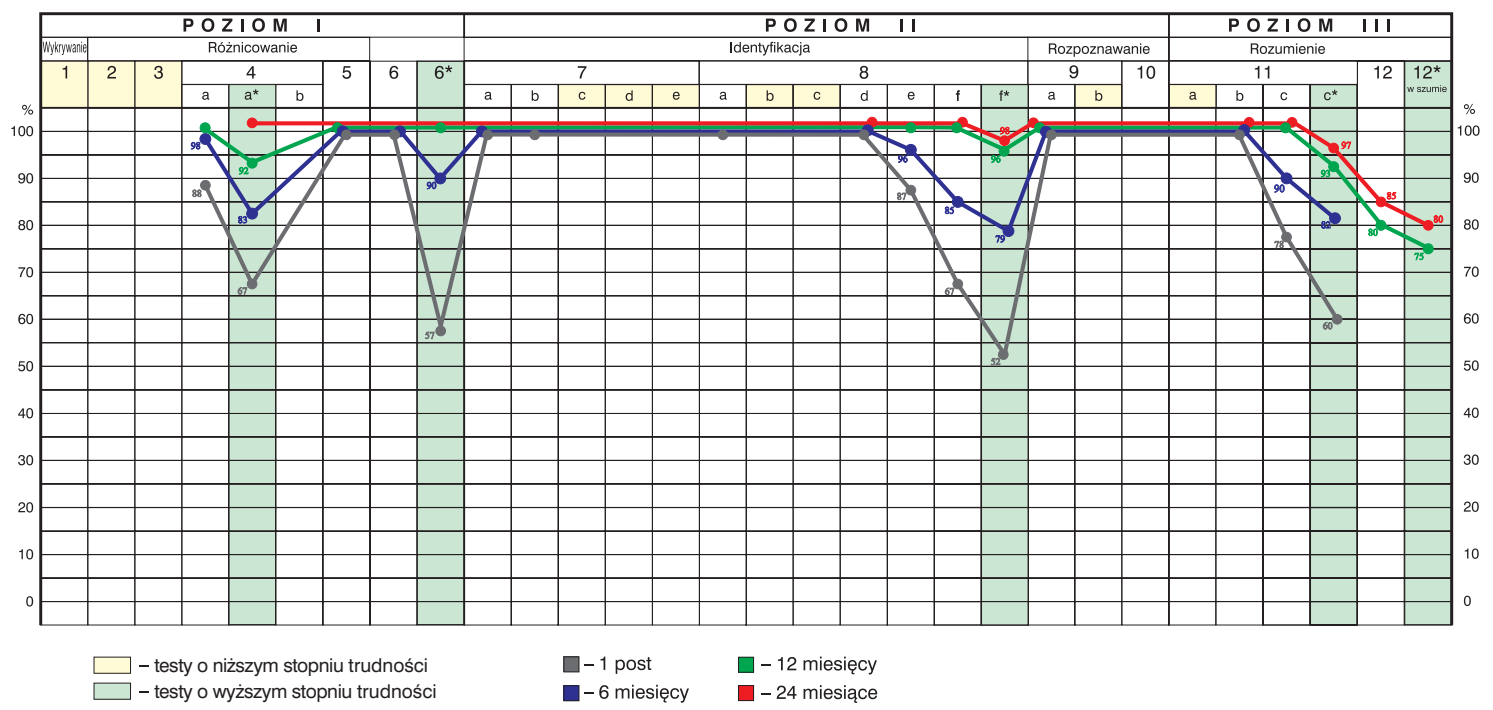

Rycina 1B. Profil Umiejętności Słuchowych pacjentka E.D. 
Pacjentka E. M.

Pacjentka zgłosiła się z postępującym ubytkiem słuchu. Początkowo pomimo trudności radziła sobie bez stosowania dodatkowych urządzeń wspomagających słyszenie, jednak na rok przed operacją zdecydowała się na dobór wzmocnienia akustycznego do ucha lewego. Dodatkowym problemem były szumy uszne, które w subiektywnej ocenie pacjenta były bardziej dokuczliwe w uchu prawym. Pomimo systematycznego korzystania $\mathrm{z}$ aparatu słuchowego do ucha lewego, odbiór mowy został w znaczny sposób ograniczony i odbywał się jedynie w oparciu o kanał wzrokowo-słuchowy. Podczas konsultacji kwalifikującej do wszczepienia implantu ślimakowego wykonano test identyfikacji zdań w aparacie słuchowym, w którym wynik poprawnego rozumienia wyniósł jedynie $28 \%$. Pacjentka reagowała na głos, na początek-koniec sygnału, nie różnicowała wyrazów, głosek. Pacjentka wycofała się z życia społecznego, ograniczyła kontakty ze znajomymi i dalszą rodziną. Żyła w poczuciu wyobcowania i niezrozumienia dla własnego problemu (Rycina 2A,B).
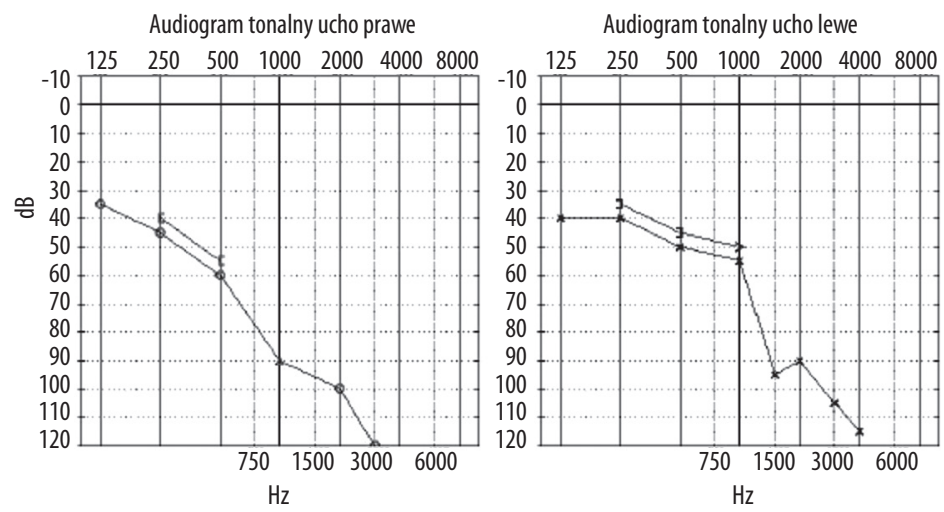

Rycina 2A. Audiogram pacjentka E.M.

\section{PROFIL UMIEJĘTNOŚCI SŁUCHOWYCH PACJENTA}

Pacjent ........M.

Wiek w momencie zaimplantowania ....53 lata

Przyczyna głuchoty gluchota postępująca - postlingwalna
Typ implantu HYBRID(EAS) / bezaparatunadrugie ucho

Data pierwszego podłączenia procesora mowy 09. 07.2009

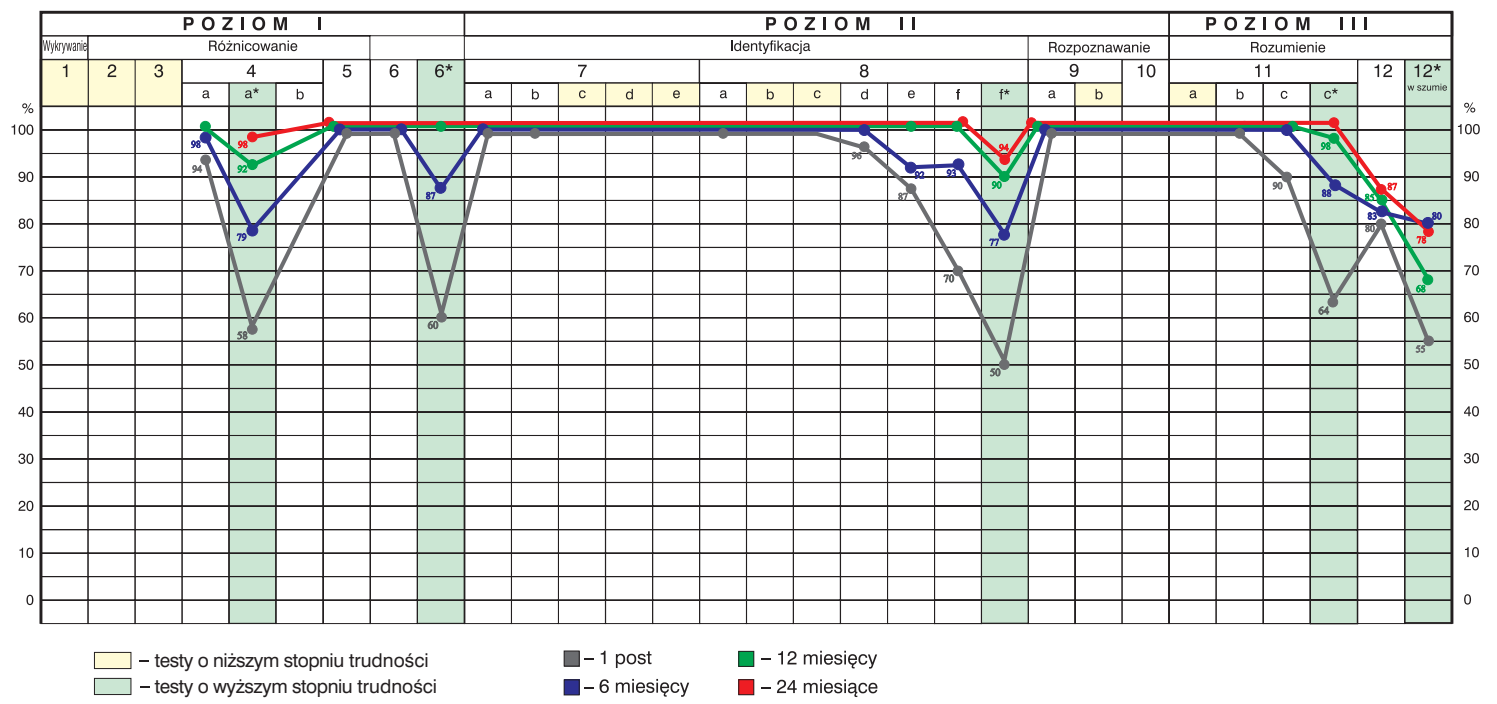

Rycina 2B. Profil Umiejętności Słuchowych pacjentka E.M. 


\section{Pacjent K.K.}

Pacjent postlingwalny, lat 58. Problemy ze słuchem zaczęły się około 30 lat temu i związane były z pracą zawodową. 24 lata temu doszło do urazu akustycznego podczas wybuchu materiału pirotechnicznego, co spowodowało znaczne pogorszenie słyszenia. Od tego momentu słuch stale się pogarszał. Od 13lat korzysta $\mathrm{z}$ aparatu słuchowego do ucha lewego. Przed operacją pacjent nie rozumiał mowy, odczytywał komunikaty z ust (Rycina 3A,B).
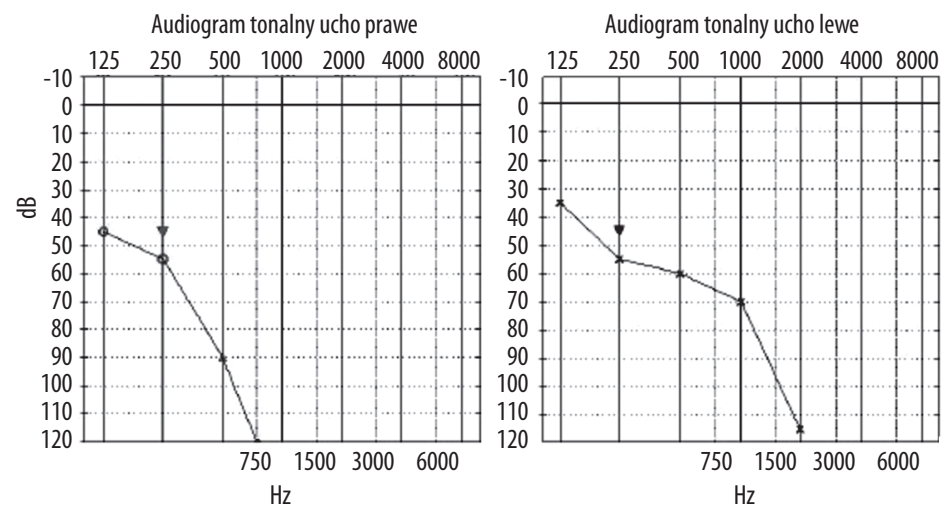

Rycina 3A. Audiogram pacjenta K.K.

\section{PROFIL UMIEJĘTNOŚCI SŁUCHOWYCH PACJENTA}

Pacjent ........ K.

Wiek w momencie zaimplantowania $\ldots . .58$ lat

Przyczyna gluchoty uraz akustyczny - postlingwalna
Typ implantu DUET (EAS)/aparat nadrugie ucho

Data pierwszego podłączenia procesora mowy

17. 05.2009

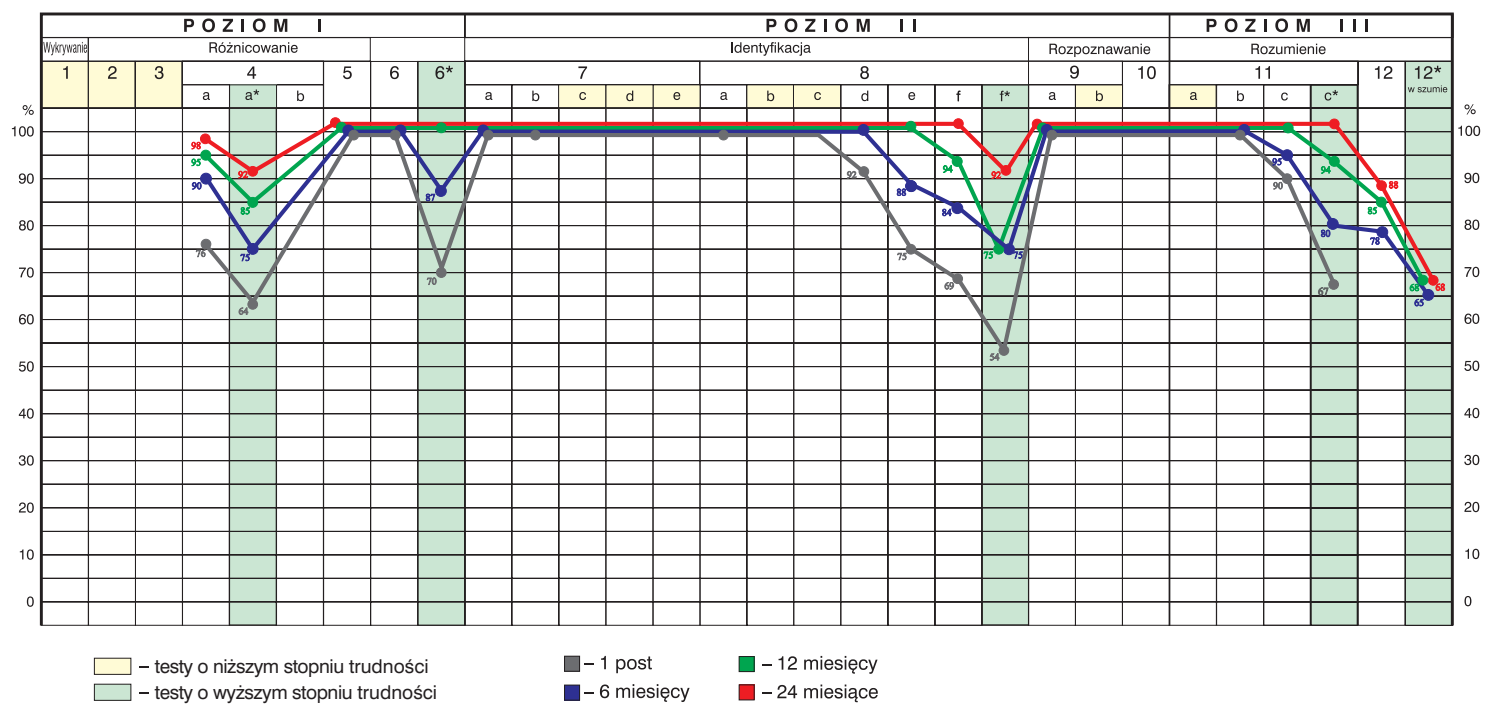

Rycina 3B. Profil Umiejętności Słuchowych pacjenta K.K.

\section{Wnioski}

Uzyskiwane przez pacjentów wyniki potwierdziły, że materiał do monitorowania efektów rehabilitacji zaproponowany pilotażowo dla omawianej grupy pacjentów, ma wartość diagnostyczną. Zadania łatwiejsze, tj. te próby, w których pacjenci uzyskiwali wynik 100\% wykonania stanowił element zachęty i motywacji, dawał również poczucie stabilności nabytych umiejętności słuchowych. Zadania zmodyfikowane, choć sprawiające pacjentom większą trudność, lepiej ilustrowały następujący po operacji progres. Formuła profilu umiejętności słuchowych powstającego z osiąganych przez pacjentów wyników, sprawdza się także wobec osób z częściową głuchotą. Pacjentom pozwala na łatwe porównywanie osiąganych rezultatów, a terapeutom na planowanie najbardziej skutecznego treningu słuchowego. Kolejne osoby po przebytej operacji i aktywacji systemu implantu ślimakowego objęte zostaną obserwacją z wykorzystaniem zaproponowanych narzędzi.

Planowane są prace nad materiałem do ćwiczeń słuchowych, a następnie nad zmodyfikowanym profilem umiejętności słuchowych także dla młodszych pacjentów z częściową głuchotą. 


\section{Piśmiennictwo:}

1. Finitzo-Hieber T., Gerling I.J., Matkin N.D., Cherow-Skalka E.: A sound effects recognition test for the pediatric audiological evaluation. Ear Hear, 1980; 1(5): 271-76

2. Skarżyński H., Lorens A., Piotrowska A.: A new method of partial deafness treatment. Med Sci Monit, 2003; 9(4): CS20-24

3. Skarżyński H., Lorens A., Piotrowska A., Skarżyński P.: Hearing preservation in partial deafness treatment. Med Sci Monit; 2010; 16(11): CR555-62
4. Skarżyński H., Szuchnik J., Mueller-Malesińska M.: Profil umiejętności słuchowych (W:) Implanty ślimakowe-rehabilitacja. Warszawa. Stowarzyszenie Przyjaciół Osób Niesłyszących i Niedosłyszących „Człowiek-Człowiekowi”, 2004; 90-112

5. Skarżyński H., Szuchnik J., Mueller-Malesińska M.: Narzędzia badawcze stosowane do oceny realizacji programu. (W:) Implanty ślimakowe-rehabilitacja. Warszawa. Stowarzyszenie Przyjaciół Osób Niesłyszących i Niedosłyszących „Człowiek-Człowiekowi", 2004; 72-90 